\title{
Locally Advanced Unresectable Prostate Adenocarcinoma
}

National Cancer Institute

\section{Source}

National Cancer Institute. Locally Advanced Unresectable Prostate Adenocarcinoma. NCI

Thesaurus. Code C156289.

A prostatic adenocarcinoma that has spread from its original site of growth to nearby tissues or lymph nodes and is not amenable to surgical resection. 